\title{
Bronisława Woźniczka-Paruzel
}

Instytut Informacii Naukowej i Bibliologii Uniwersytet Mikołaja Kopernika w Toruniu e-mail: bwp@umk.pl

\section{Bibliotekarz w sieci stereotypów i uprzedzeń - o postawach wobec osób z niepełnosprawnością czytelniczq̨}

\section{Objaśnienia wstępne}

\begin{abstract}
$\mathrm{O}^{\mathrm{d}}$ kilkunastu lat funkcjonuje $\mathrm{w}$ obiegu naukowym określenie persons with reading disability, czyli osoby z niepetnosprawnościq czytelnicza. Zostało ono wprowadzone w języku angielskim za sprawą International Federation of Library Associations (dalej: IFLA), a wkrótce potem rozpowszechniło się w krajach europejskich, trafiając do wielu języków narodowych, w tym - do polskiego, w postaci kalki językowej z angielskiego, podobnie zresztą jak termin niepełnosprawność/niesprawność czytelnicza. Wprawdzie na gruncie polskim oba pojęcia nie doczekały się definicji encyklopedycznych, ale poświęcono im już kilka omówień, które były przedstawiane na ogół w kontekście obsługi bibliotecznej i informacyjnej osób z różnymi rodzajami niepełnosprawności lub przy okazji rozważań dotyczących ich edukacji ${ }^{1}$.
\end{abstract}

${ }^{1}$ Szerzej o problemach terminologicznych pisałam już we wcześniejszych artykułach, zob. B. Woźniczka-Paruzel, Osoby z niesprawnościami czytelniczymi w bibliotece - sygnalizacja problemu, „Acta Universitatis Nicolai Copernici (dalej cyt. Acta UNC), Bibliologia IV, Nauki Humanistyczno-Społeczne", z. 340, Toruń 2000, s. 405-406. Terminem osoby $z$ niepełnosprawnościami (czasem - z niesprawnościami) czytelniczymi posługuje się obecnie wielu badaczy polskich. 
Najogólniej rzecz ujmując, niepełnosprawność czytelnicza to trwała lub czasowa niezdolność do korzystania z tradycyjnie wydawanych publikacji czarnodrukowych, wywołana jakąś niepełnosprawnością, lub ograniczenie tej zdolności, a osoby z niesprawnościami czytelniczymi to ludzie, którym różnego rodzaju dysfunkcje uniemożliwiają lub utrudniają - w sensie fizycznym, intelektualnym lub społecznym - odbiór wydawnictw publikowanych standardowo ${ }^{2}$.

Warto podkreślić, że obecnie coraz częściej w literaturze anglojęzycznej oraz w aktywności IFLA jest używane mniej stygmatyzujące określenie print disabilities, trudne do dosłownego przełożenia na język polski, które nie eksponuje niepełnosprawności czytelniczej, ale wskazuje wyłącznie na niemożność dostępu do publikacji drukowanych konwencjonalnie. W obrębie społeczności tworzonej przez osoby z tego typu ograniczeniem mieszczą się ludzie z trudnościami w uczeniu się, z uszkodzonym wzrokiem oraz z dysfunkcjami fizycznymi ${ }^{3}$. Rodzaje ich niepełnosprawności są bardzo zróżnicowane i stwarzają odmienne bariery w dostępie do piśmiennictwa, ale osoby należące do tych grup łączy to, że nie są w stanie - chociaż z rozmaitych względów - odbierać standardowych publikacji drukowanych ${ }^{4}$.

Nowe określenie, wskazujące na utrudnienia w dostępie do dokumentów wydawanych konwencjonalnie, w sposób szczególny „przylega” do ludzi niewidomych i niedowidzących, którzy z reguły są bardzo aktywnymi odbiorcami literatury, wyróżniającymi się różnorodnością zainteresowań czytelniczych i kulturalnych ${ }^{5}$. Są oni zatem sprawnymi czytelnikami, jeśli forma dokumentów piśmienniczych jest dostosowana do ich możliwości odbiorczych, tzn. jeśli dokumenty te zostały utrwalone w dostęp-

2 Tamże, s. 406.

3 "A print disability can be a learning disability, a visual impairment or a physical disability". Cyt. za: What is a print disability? [on-line]. Recording for the Blind \& Dyslexic, Inc. [dostęp 30 listopada 2009]. Dostępny w World Wide Web: http://www.learningthroughlistening.org/About-RFB-D/Understanding-RFB-D/The-Population-RFB-D-Serves/ What-is-a-Print-Disability/63/.

4 "Although the manners in which the disability occurs are very different, they all share one characteristic: individuals diagnosed with a print disability cannot access print in the standard way", tamże.

${ }^{5}$ Potwierdzają to liczne badania - zob. np. A. Żuraw, Uczestnictwo kulturalne młodzieży niepełnosprawnej, Warszawa 1996, s. 76-77; por. też informacje na temat obsługi czytelniczej niewidomych, pochodzące ze strony internetowej Biblioteki Centralnej Polskiego Związku Niewidomych: http://www.biblioteka-pzn.org.pl/ [dostęp 30 listopada 2009]. 
nych dla nich formatach lub na nie przekonwertowane. Te formaty alternatywne (czy też specjalne materiały czytelnicze) przydatne są również innym, wymienionym wcześniej grupom osób z niepełnosprawnościami czytelniczymi. Z tego właśnie powodu działająca w obrębie IFLA Sekcja Bibliotek dla Niewidomych (ang. Libraries for the Blind Section) została przekształcona 20 marca 2009 r. w Libraries Serving Persons with Print Disabilities Section, co można przetłumaczyć jako Sekcja Bibliotek Obsługujących Osoby z Niepełnosprawnościami w Odbiorze Czarnodruku6 6 .

Wokół osób z niepełnosprawnościami czytelniczymi, czy może lepiej: z trudnościami w czytaniu czarnodruku, narosło wiele mitów i nieporozumień, które wynikają głównie ze stereotypowego ich postrzegania, nierzadko prowadzącego do różnego rodzaju uprzedzeń. Nie ominęły one również bibliotek, wpływając na niewłaściwe traktowanie tych osób przez bibliotekarzy lub nieodpowiednią ich obsługę. Im właśnie poświęcony jest niniejszy artykuł. Otwierają go rozważania dotyczące stereotypów w ogóle oraz ich źródeł i konsekwencji, następnie zostaną przedstawione ich różne rodzaje, zwłaszcza te, które są związane z omawianą kategorią użytkowników bibliotek i ich kontaktami z pracownikami placówek bibliotecznych, całość zaś zakończą prośby o nieutrwalanie stereotypów i wskazania, jak je przełamywać, aby - mówiąc przenośnie „wyplątać się z ich sieci”, a tym samym - właściwie prowadzić obsługę czytelniczą i informacyjną osób potrzebujących innych materiałów niż publikowane standardowo.

\section{Stereotypy - ich źródła i konsekwencje}

N ajogólniej termin stereotypy można zdefiniować jako funkcjonujące w świadomości społecznej, skrócone, uproszczone i zabarwione wartościująco obrazy rzeczywistości, odnoszące się do rzeczy, osób, grup społecznych, instytucji itp. ${ }^{7}$ Stereotypy tworzą pewne fałszywe przeświadczenia, dotyczące różnych zjawisk, w tym - innych grup społecznych. Obejmują one trzy zasadnicze komponenty: poznawczy, emocjonal-

6 "The Libraries Serving Persons with Print Disabilities Section concerns itself with library services for the blind and other people with print disabilities". Cyt. za: The Libraries Serving Persons with Print Disabilities Section [on-line]. IFLA Website [dostęp 30 listopada 2009]. Dostępny w World Wide Web: http://www.ifla.org/en/lpd.

7 Stereotyp, [w:] Wielka encyklopedia powszechna, t. 11, Warszawa 1968, s. 83. 
ny i behawioralny, a zatem są zakorzenione w świadomości oraz wpływają na uczucia i zachowania. Mogą być przyjęte przez człowieka w wyniku jego własnych obserwacji lub doświadczeń (zwykle incydentalnych) albo w drodze przejmowania poglądów innych osób, wzorców przekazywanych przez społeczeństwo i utrwalonych przez tradycję, mogą być także wynikiem procesów emocjonalnych (np. przeniesienia agresji) ${ }^{8}$.

Ze stereotypami związane są uprzedzenia, określane w naukowej literaturze psychologicznej jako postawy negatywne. Są to względnie stałe skłonności do odrzucania czegoś lub kogoś bez racjonalnych przesłanek. Można więc powiedzieć, że uprzedzenia wyrażają niechętne nastawienie człowieka do jakiegoś przedmiotu, zdarzenia, idei czy innej osoby lub grupy osób ${ }^{9}$. Często sprzyjają kształtowaniu się stereotypów lub też ze stereotypów wynikają. Nierzadko na uprzedzenia składają się całe zbiory takich uproszczeń, prowadzących do postaw z dominującym komponentem emocjonalnym o znaku negatywnym, które motywują do działania, wywołując niechęć, agresję werbalną i czynną oraz dyskryminację ${ }^{10}$.

Niemal każda grupa społeczna ma przypisane jakieś stereotypy. Im jest bardziej wyraziście wyodrębniona albo obca, tym łatwiej podlega stereotypizacji. Ponieważ ludzie, którzy mają trudności z odbiorem standardowo wydawanych publikacji, są dotknięci jakąś niepełnosprawnością, wywołującą te trudności, bardzo często wyróżniają się wśród osób sprawnych. Dlatego też nie brakuje związanych z nimi stereotypów, którym towarzyszą uprzedzenia i niewłaściwe postawy ${ }^{11}$.

${ }^{8}$ Przemyślenia własne, na podstawie prac: W. G. Stephan, C. W. Stephan, Wywieranie wpływu przez grupy, Gdańsk 2003; I. Kurcz, Zmiana stereotypów: jej mechanizmy i granice, [w:] Stereotypy i uprzedzenia. Uwarunkowania psychologiczne i kulturowe, pod red. M. Kofty, A. Jasińskiej-Kani, Warszawa 2001.

9 Zob. Psychologia, t. 3, pod red. J. Strelau, Gdańsk 2000, s. 79. W pewnym zakresie omawiałam ten temat w referacie Bibliotekarz $w$ środowisku niepełnosprawnych, wygłoszonym na Ogólnopolskiej Konferencji Naukowej Bibliotekarz: uniwersalność i innowacyjność profesji, Bydgoszcz, 14-15 maja 2009 r., Uniwersytet Kazimierza Wielkiego (materiały pokonferencyjne w druku).

${ }_{10}$ Z. Chlewiński, Stereotypy, struktura, funkcje, geneza. Analiza interdyscyplinarna, [w:] Stereotypy i uprzedzenia, pod red. Z. Chlewińskiego, Warszawa 1992, s. 13-14.

${ }^{11} \mathrm{~J}$. Miluska, Obrazy społeczne grup narażonych na dyskryminację. Uwarunkowania społeczno-demograficzne i psychologiczne, Poznań 2008, s. 7, 349; zob. też B. Weigel, Stereotypy i uprzedzenia etniczne u dzieci i młodzieży, Warszawa 1999. 


\section{Stereotypowe postrzeganie osób niepełnosprawnych jako zbiorowości}

Społeczność ludzi dotkniętych różnymi rodzajami niepełnosprawnoŚci, które tkwią u podstaw ich trudności z odbiorem czarnodruku, jest bardzo zróżnicowana, ale w świadomości potocznej funkcjonuje wiele obiegowych opinii nie tylko na temat konkretnych ich grup, lecz przede wszystkim całej zbiorowości niepełnosprawnych. Wynika to z procesu kategoryzacji społecznej, który jest odmianą bardziej ogólnej tendencji generalizowania. Polega ona na uogólnianiu cech przynależnych członkom tej samej kategorii, w tym wypadku - ludziom niepełnosprawnym w ogóle. Kategoryzacja społeczna prowadzi do postrzegania ich jako pewnej całości, która odróżnia się od innych grup, tworzonych przez osoby zdrowe, pozbawione dysfunkcji i w pełni sprawne ${ }^{12}$.

Z badań wynika, że niepełnosprawni są postrzegani w sposób skrajny: $z$ jednej strony - to ludzie „biedni” i „nieszczęśliwi”, a więc budzący litość i współczucie z powodu nieszczęść, jakie na nich spadły, z drugiej „dzielni” i „bohaterscy”, ponieważ pokonują tyle przeciwności losu'13. Do tego dochodzą przekonania o tym, że są „niezaradni” i „zależni”, „bierni” i „nieproduktywni”, a zatem - trzeba się nimi zajmować, wspomagać ich, nieść im pomoc i na nich łożyć, co w niektórych wywołuje niechęć, zniecierpliwienie, lub nawet złość. Niekiedy powodują strach, wynikający z podświadomych obaw typu: „on/ona coś nam może zrobić” lub „nam się to też może przytrafić". Najpowszechniejsze wszakże jest zakłopotanie, ponieważ zdecydowana większość Polaków nie wie, jak zachować się wobec osoby niepełnosprawnej, bez względu na to, jaką dysfunkcją jest ona dotknięta ${ }^{14}$.

12 J. Miluska, dz. cyt., s. 12-13.

${ }^{13}$ P. Stanisławski, Od ofiary do herosa - jak nas pokazuja media. Magazyn Integracja [on-line] 2003, nr 5 [dostęp 30 listopada 2009]. Dostępny w World Wide Web: http:// www.niepelnosprawni.pl/ledge/x/3822.

${ }^{14}$ Zob. D. Chmielewska-Banaszak, W matni stereotypów. Puls. Pismo Obywatelskie [on-line] 2008, wrzesień [dostęp 30 listopada 2009]. Dostępny w World Wide Web: http://www.puls.ctinet.pl/index.php?bmF2PTImZGJpX3Jvaz0yMDA4JmRiaV9taWVzaWFjPTkmZGJpX2lkPTc1NA==; zob. też A. Twardowski, Postawy otoczenia społecznego wobec osób niepełnosprawnych i ich rodzin, [w:] Dziecko niepełnosprawne $w$ rodzinie, pod red. I. Obuchowskiej, Warszawa 1991, s. 35-39; A. Bieganowska, Model niepełnosprawności w mediach a postawy wobec osób niepełnosprawnych, „Szkoła Specjalna” 2005, nr 5, s. 362 . 
Nieadekwatne postawy, uprzedzenia i emocje, stanowiące „pochodne" stereotypowego postrzegania ludzi z różnymi niepełnosprawnościami, wynikają z prostego faktu: respondenci nie mają z nimi bliskich, bezpośrednich kontaktów, a zatem - nie znają ich, niewiele o nich wiedzą. Jak wskazuje sondaż Ośrodka Badań Opinii Publicznej z 2002 r. „Społeczna percepcja niepełnosprawności i niepełnosprawnych w Polsce", aż dwie trzecie ankietowanych (62\%) twierdziło, że w ogóle nigdy nie kontaktowało się bliżej z osobami niepełnosprawnymi lub ich rodzinami ani w pracy, ani w domu i wśród znajomych ${ }^{15}$. Bardzo zbliżone są wyniki badań, które wśród Polaków przeprowadziła w 2007 r. Jolanta Miluska, zajmująca się obrazami społecznymi grup narażonych na dyskryminację, ale co należy podkreślić - jej badania związane z potocznymi wyobrażeniami o niepełnosprawnych świadczą o tym, że stopniowo zanikają, zwłaszcza wśród ludzi młodych, zdecydowanie niechętne wobec nich nastawienia i postawy, chociaż nadal niewiele osób kontaktuje się z nimi osobiście ${ }^{16}$.

Brak konkretnej wiedzy i osobistych doświadczeń umacnia funkcjonowanie stereotypów, silnie dających o sobie znać zwłaszcza w stosunku do osób o ciężkiej i/lub widocznej niepełnosprawności (bez względu na jej rodzaj), co prowadzi do społecznego naznaczania.

Naznaczanie (etykietowanie) jest powszechnym sposobem reagowania na „innych”, to znaczy na tych spośród nas, których zachowanie lub wygląd odbiega od normy. Gdy poziom tolerancji na inność jest niski [...] Osoby niepełnosprawne [...] ulegają naznaczaniu, czyli zostają „zaetykietowane". Etykiety najczęściej wyrażają się w następujących przekonaniach: „słaby, bo potrzebujący mojej pomocy”, „gorszy, bo nie rozumie swojej sytuacji tak dobrze jak ja”, „obcy, bo pochodzi ze świata, którego nie znam i nie chcę poznać"17.

Etykiety wywołują stereotypowe zachowania: narzucanie się z pomocą, nadmierną opiekuńczość, dawanie nieproszonych rad, podpowiadanie „właściwych” sposobów zachowań, decydowanie za osobę niepełno-

${ }^{15}$ Społeczna percepcja niepełnosprawności i niepełnosprawnych w Polsce. Komunikat z badania zrealizowanego na zlecenie IMPEL S.A. [on-line]. Warszawa: TNS OBOP, 2002, $33 \mathrm{~s}$. [dostęp 30 listopada 2009]. Dostępny w World Wide Web: http://www.tns-global.pl/abin/r/1293/143-02.pdf; por. też A. Ostrowska, Niepełnosprawni w społeczeństwie, Warszawa 1994.

16 Por. J. Miluska, dz. cyt., s. 323-324.

17 D. Chmielewska-Banaszak, dz. cyt. 
sprawną albo unikanie kontaktów z nią ${ }^{18}$. Do tego dochodzi wspomniana wcześniej kategoryzacja społeczna, odpowiedzialna przede wszystkim za zjawisko tendencyjnego przetwarzania informacji na temat grupy „innych". Jej członkowie są traktowani niechętnie i podejrzliwie, są pomijani, izolowani i oceniani gorzej ${ }^{19}$.

Rzecz charakterystyczna: w powszechnej świadomości społecznej niepełnosprawność jest postrzegana przede wszystkim przez pryzmat uszkodzeń narządów ruchu. Stereotyp ten, utrwalony zresztą przez międzynarodowy piktogram osoby na wózku inwalidzkim, czasami daje o sobie znać również w środowisku bibliotekarzy. Niesie to za sobą określone konsekwencje: przeszkody w dostępie do biblioteki, jej zbiorów i usług są kojarzone głównie z barierami architektonicznymi, ich likwidacja zaś jest utożsamiana $\mathrm{z}$ dostosowaniem placówki dla niepełnosprawnych w ogóle. 0 tym uproszczonym pojmowaniu niepełnosprawności świadczą m.in. sprawozdania bibliotek publicznych, jakie napływają do Głównego Urzędu Statystycznego (dalej: GUS), oraz opracowywane na podstawie danych GUS statystyki typu: „Biblioteki Publiczne w Liczbach”, gdzie mówi się wyłącznie o lokalach bibliotecznych przystosowanych do obsługi osób z dysfunkcjami ruchu, z pominięciem potrzeb użytkowników z innymi rodzajami niepełnosprawności ${ }^{20}$.

Nawiasem mówiąc, zaliczanie osób z uszkodzeniami fizycznymi do niepełnosprawnych czytelniczo, czy nawet węziej - do osób niezdolnych do korzystania z publikacji czarnodrukowych, wydaje się nieco „na wyrost”. Zdecydowana ich większość nie ma problemów z odbiorem standardowo publikowanych wydawnictw, nie potrzebuje zatem specjalnych materiałów czytelniczych, a wyłącznie odpowiedniego sprzętu, który umożliwi im fizyczny dostęp do publikacji standardowych, np. w przypadku niemożności utrzymania książki w ręku lub samodzielnego wertowania stron - wystarczają odpowiednie pulpity i urządzenia do przewracania kartek, w przypadku korzystania z wózka inwalidzkiego

\footnotetext{
18 Tamże.

19 Przemyślenia własne, inspiracje zaczerpnięte z: J. Miluska, dz. cyt., s. 13.

${ }^{20}$ Zwróciła na to uwagę M. Fedorowicz w rozprawie Człowiek niepełnosprawny w bibliotece publicznej. Wzorzec działań wobec doświadczeń międzynarodowych oraz polskich realiów [masz. przygotowywany do druku], Toruń 2009; zob. też Biblioteki Publiczne w Liczbach [on-line]. Biblioteka Narodowa: Pracownia Bibliotekoznawstwa, Instytut Książki i Czytelnictwa [dostęp 30 listopada 2009]. Dostępny w World Wide Web: http:// www.bn.org.pl/index.php/zasoby-cyfrowe-i-linki/elektroniczne-publikacje-bn/biblioteki-publiczne-w-liczbach.
} 
- odpowiednie rozwiązania architektoniczne i dostosowanie przestrzeni bibliotecznej oraz sprzętów (w tym - stanowisk komputerowych) do ich potrzeb, w przypadku zaś unieruchomienia - dostarczanie materiałów czytelniczych do domu ${ }^{21}$.

W związku z tym, że zdrowie i bycie osobą zdrową, sprawną fizycznie i umysłowo jest społeczną i kulturową normą, niepełnosprawność - bez względu na jej rodzaj - staje się jej zaprzeczeniem. Dlatego też wszystkie odchylenia od normy nią spowodowane podlegają stygmatyzacji, której instrumentem często są negatywne stereotypy. Niekiedy wynikają one z powierzchownych obserwacji pojedynczych zachowań, na podstawie których ludzie pełnosprawni przypisują osobom z różnymi rodzajami niepełnosprawności te same, stereotypowe cechy. W rezultacie postrzegają je jako osoby samotne i wycofujące się, czemu towarzyszy przekonanie, że nie można im powierzyć żadnej samodzielnej pracy, a to z kolei prowadzi do wykluczania ich z różnych form aktywności, powodującego izolację i dyskryminację - również na rynku pracy. Zdarza się, że sami niepełnosprawni, podświadomie poddając się tym stereotypom, „wchodzą w role", tj. ograniczają własną aktywność, demonstrują brak zaufania do siebie i zależność od innych albo zachowują daleko posuniętą ostrożność i powściągliwość wobec innych, lub nawet odrzucają wszelką pomoc. Takie zachowania, często jednostkowe, mogą stanowić podstawę uogólnionych przekonań na temat wszystkich niepełnosprawnych. Niepełnosprawność działa tu jako niekorzystna cecha centralna, odpowiedzialna za negatywny efekt w postrzeganiu społecznym ${ }^{22}$, co czasem daje o sobie znać również w bibliotece.

Zarówno-z publikacji polskich, jak i zagranicznych wynika, że kontaktom bibliotekarzy z osobami o różnych rodzajach niepełnosprawności często towarzyszy zakłopotanie, a czasem i lęk, aby nie dotknąć ich niewłaściwym zachowaniem lub uwagami, co prowadzi do zbyt ostentacyjnego manifestowania otwartości, traktowania ich w sposób szczególny, nadmiernego śpieszenia z pomocą, wyręczania ich w czynnościach, które potrafią sami wykonać itp. ${ }^{23} \mathrm{~W}$ rezultacie rodzi się kolejny stereotyp: ob-

${ }^{21}$ Szerzej pisała o tym M. Fedorowicz, dz. cyt.; por. też B. Woźniczka-Paruzel, Osoby z niesprawnościami..., s. 407.

22 J. Miluska, dz. cyt., s. 31-32.

${ }^{23} 0$ takich postawach pisze M. Fedorowicz, dz. cyt., s. 120; z zagranicznych prac można wymienić: D. Mudimann [et al.], Open to all? The public library and social exclusion, Vol. 2, [London] 2000, s. 18. 
sługa niepełnosprawnych zajmuje wiele czasu ${ }^{24}$. Jak zaznaczają sami zainteresowani, odczuwają te zabiegi jako formy swoistego „ubezwłasnowolnienia", które odbierają im samodzielność i są nieadekwatne do rodzaju lub stopnia ich niepełnosprawności, a czasami czują również, że są one „podszyte” nieumiejętnie skrywaną litością, która ich bardzo drażni²5.

\section{Substereotypy różnych rodzajów niepełnosprawności}

udzie wytwarzają i przyjmują nie tylko ogólne stereotypy niepełnosprawności, ale konstruują również ich podtypy i odpowiadające im substereotypy, odnoszące się do różnych rodzajów niepełnosprawności. Z nimi także wiąże się wiele nieporozumień lub uprzedzeń, które kształtują określone postawy - nie zawsze wszakże negatywne. Warto zaznaczyć, że ze wszystkich grup osób, mieszczących się w społeczności z trudnościami w odbiorze standardowo publikowanych dokumentów, największą sympatię budzą ludzie z uszkodzonym analizatorem wzroku, zwłaszcza całkowicie niewidomi, którzy „zaopatrzeni” są w stosowne atrybuty: białą laskę lub psa przewodnika, co powoduje, że zdecydowana większość widzących idzie im z pomocą. Pomoc ta jest jednak także niekiedy „na wyrost” i wynika z postrzegania niewidomych jako osób bezradnych, mało samodzielnych, zależnych od innych i wymagających opieki. Warto też odnotować, że uchodzą oni za ludzi uległych i melancholijnych ${ }^{26}$. Wyraźnie tu widać, że ich substereotyp w znacznym stopniu powiela przekonania na temat wszystkich niepełnosprawnych, bez uwzględnienia specyfiki omawianej dysfunkcji, a przede wszystkim - bez brania pod uwage zróżnicowań jednostkowych i indywidualnych możliwości.

W sposób podobny do opisanego reagują pracownicy bibliotek, przy czym - jak zwierzają się sami niewidomi, którzy korzystają z placówek dostępnych dla wszystkich, a nie z wyspecjalizowanych oddziałów - bibliotekarze traktują ich niekiedy tak, jakby byli niepełnosprawni intelektualnie lub nie słyszeli. Mówią do nich bądź językiem infantylnym, bądź

${ }^{24}$ Por. Vademecum bibliotekarza: praktyczne i aktualne informacje dla bibliotekarzy, pod red. L. Bilińskiego, Warszawa 2002, rozdział 7.6.3: Prawno-organizacyjne aspekty czytelnictwa osób z niepełnosprawnościami, s. 7.

${ }^{25} \mathrm{O}$ takich odczuciach informowali mnie moi studenci z niepełnosprawnością ruchu i uszkodzeniami wzroku, których nazwisk, z oczywistych względów, nie mogę tu przytoczyć.

${ }^{26}$ J. Miluska, dz. cyt., s. 31. 
za głośno, co ich bardzo denerwuje. 0 naiwnych „zdziwieniach” w rodzaju: „Po co panu tyle książek?, Jak je pan przeczyta?”, aż wstyd tutaj wspominać ${ }^{27}$.

Wydaje się, że pracownicy bibliotek powinni wiedzieć więcej o tej grupie użytkowników, tym bardziej że - jak już sygnalizowano - są oni aktywnymi czytelnikami, sprawnymi czytelniczo wtedy, gdy mogą korzystać z materiałów alternatywnych (np. wydawnictwa brajlowskie, książki mówione, teksty utrwalone cyfrowo) oraz odpowiednich urządzeń i oprogramowania umożliwiającego dostęp do komputera i dokumentów elektronicznych. Niejednokrotnie również są osobami znacznie bardziej samodzielnymi, niż się wydaje widzącym. Odnosi się to jednak przede wszystkim do niewidzących od urodzenia, a nie do ociemniałych, którzy w „świecie ciemności” odnajdują się znacznie gorzej, a pewne umiejętności, zwłaszcza gdy późno utracili wzrok, są dla nich niedostępne, więc faktycznie wymagają większej pomocy ${ }^{28}$.

W społeczności osób z niepełnosprawnościami czytelniczymi, które mają problemy z odbiorem czarnodruku, chociaż nie w sensie fizycznym, ale percepcyjnym, mieszczą się też ludzie z uszkodzonym narządem słuchu, a zwłaszcza ci, którzy nie słyszą od urodzenia i posługują się językiem migowym. Wokół nich narosło szczególnie wiele nieporozumień, wynikających z nikłej wiedzy na temat ich funkcjonowania społecznego, w tym - ich uczestnictwa w kulturze i lekturze. Jest to zrozumiałe o tyle, że w świecie, w którym podstawą komunikacji jest język werbalny, stanowią oni mało znaną mniejszość językową, z którą słysząca większość zwykle nie potrafi nawiązać kontaktu (dotyczy to również bibliotekarzy i badaczy zjawisk czytelniczych). W rezultacie tworzą się „światy równoległe", co sprzyja powstawaniu stereotypów i uprzedzeń. Wpływają one negatywnie na wzajemne relacje, w poważnym stopniu utrudniając „mieszkańcom świata ciszy” dostęp do czytania i czytelnictwa oraz - szerzej rzecz ujmując - do informacji i edukacji. Należy przy tym podkreślić, że sami niesłyszący od urodzenia nie uważają się za niepełnosprawnych, lecz za odmienną językowo i kulturowo grupę „cudzoziemców” wśród

${ }^{27}$ D. Chmielewska-Banaszak, dz. cyt.; por. dyskusje samych niepełnosprawnych na temat stereotypów: Człowiek bez barier [on-line]. GoldenLine.pl [dostęp 30 listopada 2009]. Dostępny w World Wide Web: http://www.goldenline.pl/forum/czlowiek-bezbarier/848332.

${ }^{28}$ O reakcjach ociemniałych w ich dorosłym życiu pisano już wiele. Moje opinie w tej kwestii zaczerpnęłam ze zwierzeń przyjaciół, którzy wcześniej pracowali m.in. jako dziennikarze, kierownicy działów bibliotek naukowych itp. 
słyszących, dowodząc, że traktowanie ich jako niemych stanowi rezultat stereotypowego podejścia do języka, utożsamionego w kulturze słyszących z mową foniczną ${ }^{29}$. Tymczasem w świadomości potocznej osoby głuche to ludzie kalecy i ograniczeni umysłowo, którzy nie tylko nie słyszą i nie mówią, ale także myślą, a nawet widzą inaczej, mają słabą pamięć i ograniczone uczucia, a do tego są bardzo niecierpliwi i nerwowi ${ }^{30}$.

Te krzywdzące opinie, wynikające z powierzchownego postrzegania osób głuchych, które np. w trakcie rozmów prowadzonych w języku migowym żywiołowo gestykulują, wydając przy tym nieartykułowane dźwięki, prowadzą do negatywnych postaw wobec nich i licznych uprzedzeń. Na „gruncie” bibliotecznym towarzyszą im czasami inne stereotypowe opinie w rodzaju: „Oni nie słyszą, ale przecież widzą, więc mogą czytać!” lub: „Oni bywają w bibliotekach, ale tego nie widać, bo głuchota jest niewidoczna"31. Świadczą one o tym, że nieznana jest skala trudności, jakie towarzyszą niesłyszącym $w$ nauce czytania i pisania, a tym samym - w ich uczestnictwie w procesach komunikacji pisemnej ${ }^{32}$. Wydaje się, że do pracy z nimi w warunkach biblioteki otwartej, tj. poza ośrodkami szkolno-wychowawczymi dla dzieci i młodzieży z uszkodzonym słuchem, bibliotekarze są przygotowani bardzo słabo, m.in. ze względu na bariery komunikacyjne (nie znają na ogół języka migowego) oraz znaczną ignorancję związaną ze specyfiką omawianej niepełnosprawności. Nic więc dziwnego, że w bibliotece ta grupa faktycznie bywa sporadycznie, a jej czytelnictwo rozwija się z ogromnym trudem ${ }^{33}$. Należy dodać, że ci głusi, którzy opanowali mowę foniczną, a bywają w ogólnodostępnych bibliotekach, skarżą się, że z powodu niewyraźnej, bełkotliwej lub głośnej i głuchej wymowy, wynikającej z braku autokontroli słuchowej, są traktowa-

${ }^{29}$ Zob. A. Zbieg, A. Szwedowicz, Głusi - milczacy cudzoziemcy [on-line]. Slaboslyszacy.pl [dostęp 30 listopada 2009]. Dostępny w World Wide Web: http://www.slaboslyszacy.pl/info,249.html.

${ }^{30}$ J. Miluska, dz. cyt., s. 31.

31 Takie opinie, wygłaszane, niestety, przez osoby znaczące w bibliologii polskiej, wolałabym pozostawić bez stygmatyzującego ich wymienienia.

${ }^{32}$ Na temat tych trudności - zob. K. Krakowiak, Szkice o wychowaniu dzieci z uszkodzeniami słuchu, Lublin 2006; Głuchota a język, pod red. S. Grabiasa, Lublin 1994; B. Szczepankowski, Niesłyszący, głusi, głuchoniemi, Warszawa 1999.

${ }^{33}$ B. Szczepankowski, Problemy czytelnictwa w środowisku niesłyszących, [w:] Prawo do czytania. Człowiek niepełnosprawny $w$ bibliotece. Alternatywne materiały czytelnicze. Materiały z międzynarodowego seminarium, Toruń 1994, s. 55-66; U. Eckert, Problemy czytelnictwa osób niesłyszących, „Szkoła Specjalna” 1987, nr 2, s. 131-132. 
ni jak osoby nietrzeźwe, niepełnosprawne intelektualnie lub niegrzeczne, co zniechęca ich do osobistego korzystania z biblioteki ${ }^{34}$.

Jeszcze więcej stereotypów i uprzedzeń oraz niechętnych postaw związanych jest z osobami dotkniętymi niepełnosprawnościami umysłowymi, a zwłaszcza tymi ich odmianami, które są najbardziej widoczne i w powszechnym odczuciu - nieestetyczne. Chociaż wiadomo, że w tej grupie mieszczą się ludzie o różnych stopniach upośledzenia, a co za tym idzie - bardzo zróżnicowanych możliwościach, panuje dość powszechne przekonanie, że nie są oni użytkownikami bibliotek, a jeśli tak, to w systemie zamkniętym, tj. w ośrodkach szkolno-wychowawczych czy domach opieki społecznej. Tymczasem w polskiej rzeczywistości zdecydowana ich większość na co dzień przebywa w środowiskach rodzinnych, a pewna ich część, zwłaszcza z upośledzeniem lekkim lub umiarkowanym, odwiedza biblioteki ${ }^{35}$. Zważywszy na to, że niejednokrotnie wszystkie grupy osób z niepełnosprawnością intelektualną wrzuca się „do jednego worka", nieprzygotowany w tym zakresie bibliotekarz nie tylko odczuwa lęk w bezpośrednich kontaktach z nimi, ale czasem również traktuje ich - bez względu na wiek - jak małe dzieci, co znajduje m.in. wyraz w zwrotach typu: „pani zaraz da książeczkę” i innych infantylnych określeniach oraz w oferowaniu literatury dziecięcej, co wypływa z przekonania, że innych tekstów nie są w stanie zrozumiećc ${ }^{36}$.

W podsumowaniu tej części rozważań można stwierdzić, że „sieć stereotypów" wraz z towarzyszącymi im uprzedzeniami prowadzi czasem bibliotekarzy do protekcjonizmu, wyrażającego się w niedocenianiu możliwości osób z różnymi rodzajami niepełnosprawności czytelniczych, a niekiedy - do nadmiernej opiekuńczości, która utrudnia ich rozwój i zdobywanie nowych kompetencji, stanowiąc formę ubezwłasnowolnienia. Niekiedy też

${ }^{34}$ Przytaczam tu opinię jednej z moich magistrantek z uszkodzonym słuchem w stopniu znacznym. Opisy podobnych reakcji bibliotekarzy można znaleźć w opracowaniach zagranicznych - zob. D. Norlin, Helping adults with mental retardation satisfy their information needs, [w:] Information services for people with developmental disabilities: the library manager's handbook, ed. by L. L. Walling, M. M. Irvin, Westport-London 1995, s. 181-195.

${ }^{35}$ Zob. A. Korzon, Mity i stereotypy myślowe o niepełnosprawnych intelektualnie w środowisku społecznym, [w:] Człowiek z niepełnosprawnościq intelektualnq, pod red. Z. Janiszewskiej-Nieścioruk, Kraków 2004, s. 31-32.

${ }^{36} \mathrm{O}$ takich sytuacjach informowała mnie magistrantka $\mathrm{z}$ niestacjonarnych studiów 2 stopnia - matka nastolatka z niepełnosprawnością intelektualną $\mathrm{w}$ stopniu lekkim. O podobnych pisze D. J. Weber, Historical overview, [w:] Library services for the handicapped adult, ed. by J. L. Thomas, C. H. Thomas, Phoenix 1982, s. 3-11. 
przyczynia się do odrzucania ich, np. poprzez odsyłanie do wyspecjalizowanych, ale odległych ośrodków czytelnictwa chorych i niepełnosprawnych, które - jakkolwiek bardzo potrzebne - nie są w stanie zaspokoić wszystkich potrzeb czytelniczych różnych ich grup, a jednocześnie w pewien sposób ich izolują, co nie sprzyja procesowi integracji społecznej.

\section{Przelamywanie stereotypów i uprzedzeń}

W utrzymywaniu się, podtrzymywaniu, a nawet wzmacnianiu stereotypowego postrzegania ludzi niepełnosprawnych istotną rolę odgrywają określenia, jakich się w stosunku do nich używa. Słowa: „ślepiec”, „głuchoniemy”, „,inwalida”, „,kaleka”, a nawet „idiota” czy „debil” - to dawne terminy urzędowe czy medyczne, które wyszły już z obiegu oficjalnego, lecz nadal funkcjonują $w$ języku potocznym. Wyrażają one pejoratywny stosunek do ludzi z uszkodzonym wzrokiem, słuchem, niepełnosprawnościami fizycznymi i intelektualnymi, a przy tym stygmatyzują ich. Wprawdzie w środowisku pracowników bibliotek występują sporadycznie, ale w niektórych polskich publikacjach dla bibliotekarzy określenia osób z różnymi rodzajami niepełnosprawności odbiegają od terminologii przyjętej w Unii Europejskiej czy dokumentach IFLA ${ }^{37}$. Tymczasem należy podkreślić, że obecnie nawet pozornie neutralne określenie osoba niepełnosprawna jest zastępowane określeniem osoba z niepełnosprawnościq - z dopowiedzeniem, jakiego rodzaju, o czym zresztą pisali i inni, m.in. Franciszek Czajkowski ${ }^{38}$. Przeciw etykietującemu stygmatyzowaniu terminologicznemu występują także twórcy Projektu „Ustawy o wyrównywaniu szans osób z niepełnosprawnościq̨", którzy przyjęli też obowiązującą na świecie typologię niepełnosprawności ${ }^{39}$.

${ }^{37}$ Przykładowo: J. Wojciechowski, Podstawy pracy z czytelnikiem, Warszawa 1991, s. 69 - znajdujemy tu takie określenia: „stan inwalidztwa”, „inwalidzi”, „kalectwo”.

${ }^{38}$ F. Czajkowski, Rola czytania i materiałów czytelniczych $w$ rehabilitacji osób z niesprawnościami, „Acta UNC, Bibliologia II-III, Nauki Humanistyczno-Społeczne”, z. 328, Toruń 1998, s. 613-614.

${ }^{39}$ Definicja osoby z niepełnosprawnościq zob. Projekt „Ustawa o wyrównywaniu szans osób z niepełnosprawnościq" [on-line]. niepelnosprawni.pl [dostęp 30 listopada 2009]. Dostępny w World Wide Web: http://www.niepelnosprawni.pl/files/www.niepelnosprawni.pl/public/formularze/ustawa_ostateczna.pdf. Projekt w grudniu 2008 r. trafił do Sejmu RP. Opracowany został przez Stowarzyszenie Przyjaciół Integracji, przy współudziale Senatu RP i ambasady brytyjskiej. Jego bezpośredni autorzy to Hubert Izdebski, Wojciech Rogowski, Marcin Matczak i Piotr Pawłowski. 
Ustalenia tego typu „podpowiadają” nam pewne rozwiązania: otóż w aktywności bibliotecznej i pracach poświęconych osobom z niepełnosprawnościami czytelniczymi należy stosować jednolitą terminologię, neutralną semantycznie, bez stygmatyzujących określeń wynikających z niewiedzy lub uprzedzeń, trzeba również przyjąć taki podział tej społeczności, który „przylega” do zaleceń IFLA oraz propozycji zawartych w projekcie wymienionej wyżej ustawy. Umożliwi to nie tylko eliminację niewłaściwych określeń, ale także uporządkowanie - na przykład - dokumentacji i statystyk związanych z obsługą biblioteczną i informacyjną omawianej kategorii użytkowników.

Lektura projektu ustawy, której tekst obejmuje 19 rozdziałów zasadniczych, jest niezwykle pouczająca, tym bardziej że całość odnosi się do różnorakich sfer funkcjonowania człowieka w przestrzeni publicznej i społecznej. Zawarte w niej przepisy prawne wprowadzają zasady równego traktowania osób z niepełnosprawnością, przy równoczesnym wskazywaniu instrumentów prawnych, które zapobiegałyby ich dyskryminacji, stygmatyzacji i izolacji. Z punktu widzenia bibliotekarzy szczególnego znaczenia nabierają te części ustawy, które dotyczą:

- instytucji użyteczności publicznej, w tym instytucji kulturalnych, w obrębie których wymieniane są również biblioteki (np. rozdział 2, art. 11);

- informowania i gromadzenia informacji oraz podnoszenia świadomości społecznej odnośnie do osób z niepełnosprawnością (rozdział 3).

W przywołanym rozdziale trzecim czytamy m.in., że informacje adresowane do osób z niepełnosprawnością mają ukazywać się $\mathrm{w}$ formie dostosowanej do różnych rodzajów i stopni niepełnosprawności, aby były dostępne i zrozumiałe (gdy zawarte są na stronie internetowej, powinny stwarzać osobom niewidomym oraz niedowidzącym możliwość ich odczytania - z zastosowaniem dodatkowych urządzeń). Bez wątpienia takie rozwiązania ułatwiłyby znacznie życie osób z trudnościami w odbiorze standardowo publikowanych dokumentów, tym bardziej że np. - w myśl ustawy - również niesłyszący, którzy mają z tym wiele kłopotów, w kontaktach z instytucjami mieliby prawo posługiwać się polskim językiem migowym lub pismem ręcznym, a gdyby to nie gwarantowało porozumienia, organa administracji władzy publicznej byłyby zobowiązane do zapewnienia pomocy tłumacza języka migowego (rozdział 3 , art. 27-29). 
Do eliminowania stereotypowego postrzegania osób o różnych rodzajach niepełnosprawności oraz związanych ze stereotypami niewłaściwych postaw wobec nich ma - w myśl projektu ustawy - przyczynić się uwzględnienie problematyki niepełnosprawności w kształceniu oraz wychowaniu dzieci i młodzieży (rozdział 4). Dostarczenie wiedzy na temat szczególnych potrzeb osób z niepełnosprawnością ma również spowodować ich rozumienie i akceptację, zapobiegając dyskryminacji. Zbliżone funkcje ma pełnić uwzględnienie problematyki niepełnosprawności w kształceniu na poziomie szkolnictwa wyższego (rozdział 5). Szkoda tylko, że twórcy projektu zaproponowali te treści wyłącznie dla takich kierunków, jak: lekarski, lekarsko-dentystyczny, pielęgniarstwo, położnictwo, budownictwo, architektura, oraz dla specjalności przygotowującej do zawodu pracownika socjalnego, podczas gdy do tej listy można by z powodzeniem dodać jeszcze kilka, np. te kierunki, których absolwenci mają lub mogą mieć w pracy zawodowej bezpośrednie kontakty z osobami o różnych rodzajach niepełnosprawności, w tym - czytelniczej, jako wychowawcy przedszkolni, nauczyciele nauczania zintegrowanego, pedagogowie, psychologowie czy bibliotekarze.

Niemal w każdym rozdziale omawianego projektu ustawy można znaleźć artykuły lub punkty, które w pewnym zakresie odnoszą się również do rzeczywistości bibliotecznej oraz pracy z użytkownikiem biblioteki. Przykładowo: art. 41 rozdziału 7, poświęcony wyrównywaniu szans w zakresie dostępu do budynków użyteczności publicznej, nakłada obowiązek dostosowania ich do potrzeb osób z różnymi rodzajami niepełnosprawności, wskazując m.in., że należą do nich także obiekty przeznaczone na użytek szkolnictwa wyższego i kultury (a zatem - również biblioteki). Odniesienia do powinności bibliotek zawierają też rozdziały 9 i 10 (o wyrównywaniu szans w zakresie dostępu do edukacji i działalności kulturalnej), w których podkreśla się, że placówki publiczne i ich pracownicy nie mogą odmówić osobom z niepełnosprawnością uczestnictwa w organizowanych przez siebie imprezach artystycznych lub rozrywkowych oraz w innych formach prowadzonej przez siebie działalności kulturalnej.

Oczywiście, nie sposób w krótkim artykule przedstawić całości Projektu „Ustawy o wyrównywaniu szans osób z niepełnosprawnościq̨", tym bardziej że spore jego fragmenty, chociaż pozostają w pewnym związku z bibliotekami, raczej luźno wiążą się z zasadniczym problemem - eliminowaniem stereotypów w środowisku bibliotekarzy. Peł- 
ny tekst projektu jest dostępny w Internecie ${ }^{40}$. Autorka kończy tę część rozważań „nabożnym” życzeniem: oby tę ustawę udało się wprowadzić w życie.

Jak wskazuje Jacek Wojciechowski, bibliotekarz ma odgrywać rolę mediatora - pośrednika w komunikacji społecznej przebiegającej w bibliotece lub za jej sprawą, który tworzy odpowiednie zaplecze materiałów i form komunikacyjnych, dokonuje utylizacji i promocji oraz organizuje udostępnianie ${ }^{41}$. Właściwe pełnienie tej funkcji w odniesieniu do osób z niepełnosprawnościami czytelniczymi wymaga nie tylko fachowej wiedzy bibliotekarskiej, ale również sporego zasobu wiedzy na temat różnych rodzajów niepełnosprawności, które tkwią u podstaw ich trudności w dostępie do książki, prasy, informacji i samej biblioteki oraz określają ich możliwości odbiorcze. Można przypuszczać, że wiedza tego rodzaju pozwoli uniknąć potknięć, wynikających ze stereotypowego ich postrzegania, ułatwiając wzajemne kontakty i ich właściwą obsługę biblioteczną i informacyjną, dostosowaną do ich możliwości odbiorczych i potrzeb.

Wiedza to nie wszystko, ponieważ w pracy $\mathrm{z}$ omawianą kategorią użytkowników bibliotek pracownicy muszą posiadać również określone kwalifikacje, wykraczające nieco poza standard. Chyba najistotniejsze są tutaj umiejętności interpersonalne (nazywane także społecznymi, komunikacyjnymi czy interakcyjnymi ${ }^{42}$.

Ogólnie rzecz ujmując, umiejętności interpersonalne pozwalają na efektywne funkcjonowanie w sytuacjach społecznych. Składają się na nie m.in. takie zdolności, jak: pewność siebie (ale nie zadufanie), asertywność, empatia i inteligencja emocjonalna, umiejętność rozwiązywania konfliktów i negocjacji oraz realizacji celów społecznych, umiejętność radzenia sobie ze stresem oraz prowadzenia grupy, a także konsekwencja w działaniu ${ }^{43}$.

${ }^{40}$ Cały tekst projektu z wyjaśnieniami autorów zob. Projekt „Ustawa o wyrównywaniu szans osób z niepetnosprawnościq̨"...

${ }^{41}$ J. Wojciechowski, Bibliotekarstwo: kontynuacje i zmiany, Kraków 1999, s. 24.

${ }^{42}$ P. Smółka, Jak skutecznie szkolić umiejętności interpersonalne? [on-line]. Psychologia.net.pl [dostęp 30 listopada 2009]. Dostępny w World Wide Web: http://www.psychologia.net.pl/artykul.php?level=160.

43 Opracowane na podstawie publikacji S. Tokarzewskiego, Umiejętności interpersonalne nauczyciela, pedagoga, wychowawcy [on-line]. edux.pl [dostęp 30 listopada 2009]. Dostępny w World Wide Web: http://www.edukacja.edux.pl/p-1205-umiejetnosciinterpersonalne-nauczyciela.php. 
Oczywiście, tego typu umiejętności są przydatne wszystkim ludziom, a zwłaszcza tym, którzy pracują w zespołach, ale nie ulega wątpliwości, że ułatwiałyby obsługę osób z niepełnosprawnościami czytelniczymi. Warto też wiedzieć, że te złożone zdolności można wykształcić w trakcie kontaktów osobistych lub w drodze treningu. Nie będzie wówczas nadmiernej dominacji i kontrolowania omawianej kategorii użytkowników biblioteki (np. poprzez pouczanie i manipulowanie), nie będzie narzucania się czy zbytniego zaangażowania, a może uda się uniknąć niezrozumienia, chłodu w kontaktach i nadmiernego dystansu.

Kompetencje społeczne w większym stopniu wiążą się z cechami osobowości niż zdolnościami intelektu. Jakimi cechami powinien się zatem odznaczać bibliotekarz w środowisku osób z niepełnosprawnościami czytelniczymi, aby nie ulegać stereotypom? Odpowiedź na to pytanie po części już padła. Można dodać, że powinien być życzliwy, tolerancyjny wobec odmienności i pozytywnie nastawiony do swojej pracy i użytkowników biblioteki, którymi nie powinien pogardzać ani ich lekceważyć, a umieć wysłuchać. Pozostaje wierzyć, że takich bibliotekarzy jest już wielu.

\section{Wnioski końcowe}

ak wynika z dotychczasowych rozważań, stereotypy związane z osobami o różnych rodzajach niepełnosprawności często bazują na niepełnej wiedzy oraz fałszywych przekonaniach dotyczących zarówno samej niepełnosprawności i jej odmian, jak i ludzi nią dotkniętych, stanowiąc przy tym pewne przekonania zbiorowe, które trudno zmienić. Poglądom tym ulegają - często podświadomie - również bibliotekarze, co utrudnia im właściwe pełnienie funkcji mediatora w stosunku do tych użytkowników biblioteki (zarówno faktycznych, jak i potencjalnych), których określa się jako osoby z niepełnosprawnościami czytelniczymi lub z trudnościami w dostępie do standardowo wydawanych materiałów czytelniczych. Tymczasem Kodeks etyki bibliotekarza i pracownika informacji, przyjęty w naszym kraju w roku 2005, wymaga od przedstawicieli tej grupy zawodowej, aby szanowali różnice cechujące użytkowników, zawsze kierowali się zasadą równych szans i poszanowania praw człowieka, a szczególnie prawa do wolności intelektualnej oraz swobodnego dostępu do wiedzy, informacji i kultury. Ponadto - w myśl Kodeksu - powinni oni dążyć do po- 
znania zasad etycznych obowiązujących w grupach, które obsługują lub z którymi współpracują, starając się je respektować ${ }^{44}$.

Zreferowany fragment postanowień Kodeksu odnosi się do wszystkich użytkowników biblioteki, a więc i pośrednio również do osób z różnymi rodzajami niepełnosprawności. Jednakże w części trzeciej Kodeksu, zatytułowanej Bibliotekarze i pracownicy informacji wobec użytkownika, można znaleźć zapis dotyczący omawianej grupy bezpośrednio, który tak określa obowiązki pracowników bibliotek: „Rozumieją i respektują fakt, że nie wszyscy użytkownicy są w równym stopniu zdolni do odbioru informacji i korzystania z biblioteki. Starają się wyrównać ich szanse, działając ze szczególną troską na rzecz użytkowników niepełnosprawnych i znajdujących się w niekorzystnej sytuacji społecznej" ${ }^{35}$.

Przytoczone zapisy nie mają wprawdzie mocy sprawczej ani nie mogą zmusić bibliotekarzy do zmiany stereotypowego postrzegania osób dotkniętych różnymi rodzajami niepełnosprawności, ale stanowią bardzo istotny sygnał, że problemy omawianej społeczności są dostrzegane w środowisku bibliotekarskim, z którego przecież wyszli autorzy Kodek$s u$. Wiadomo też, że kodeksowe zapisy są już w wielu placówkach bibliotecznych faktycznie respektowane, co oznacza, że ich pracownicy wnoszą swój wkład w tworzenie zintegrowanego społeczeństwa otwartego, wolnego od stereotypów i uprzedzeń oraz barier i dyskryminacji. Oby te praktyki stały się powszechne.

\section{A Librarian in the trap of stereotypes and prejudices - on attitudes towards people with reading disabilities Abstract}

The paper outlines the most significant problems faced by librarians who provide library and information service to people with reading disabilities. These reflections are presented on a background of the psychological and social-cultural barriers that often lead to negative attitudes towards people with disabilities and their stereotypical perception. The study also indicates the knowledge, skills

${ }^{44}$ Kodeks etyki bibliotekarza i pracownika informacji, [w:] Kodeksy etyki bibliotekarskiej na świecie. Antologia narodowych kodeksów etycznych, pod red. Z. Głębołysia i J. Tomaszczyka, Warszawa 2008, s. 226.

45 Tamże, s. 228. 
and personality traits that librarians need to have in order to prevent falling into the trap of stereotypes and prejudices, and shows how to provide quality service to people with disabilities who usually cannot use standard print publications. The article concludes with a discussion on the librarians' obligations towards users with special needs, based on a number of laws and regulations, including The Code of Ethics for the Librarians and the Information Science Employees, the IFLA recommendations and Polish Draft of the "Act on Equalizing Chances for People with Disabilities" that prevents discrimination of people with disabilities at public institutions, including the libraries. 